\title{
Effects of fire on regional evapotranspiration in the central Canadian boreal forest
}

\author{
BEN BOND-LAMBERTY*, SCOTT D. PECKHAM†, STITH T. GOWER† and \\ BRENT E. EWERS \\ *Joint Global Change Research Institute, 8400 Baltimore Avenue, Suite 201, College Park, MD 20740, USA, †Department of Forest \\ and Wildlife Ecology, University of Wisconsin, 1630 Linden Drive, Madison, WI 53706, USA, †Department of Botany, \\ University of Wyoming, 31651000 E. University Avenue, Laramie, WY 82071, USA
}

\begin{abstract}
Changes in fire regimes are driving the carbon balance of much of the North American boreal forest, but few studies have examined fire-driven changes in evapotranspiration (ET) at a regional scale. This study used a version of the Biome-BGC process model with dynamic and competing vegetation types, and explicit spatial representation of a large $\left(10^{6} \mathrm{~km}^{2}\right)$ region, to simulate the effects of wildfire on ET and its components from 1948 to 2005 by comparing the fire dynamics of the 1948-1967 period with those of 1968-2005. Simulated ET averaged, over the entire temporal and spatial modeling domain, $323 \mathrm{~mm} \mathrm{yr}^{-1}$; simulation results indicated that changes in fire in recent decades decreased regional ET by $1.4 \%$ over the entire simulation, and by $3.9 \%$ in the last 10 years (19962005). Conifers dominated the transpiration $\left(E_{C}\right)$ flux $\left(120 \mathrm{~mm} \mathrm{yr}^{-1}\right)$ but decreased by $18 \%$ relative to deciduous broadleaf trees in the last part of the 20th century, when increased fire resulted in increased soil evaporation, lower canopy evaporation, lower $E_{\mathrm{C}}$, and a younger and more deciduous forest. Well- and poorly drained areas had similar rates of evaporation from the canopy and soil, but $E_{C}$ was twice as high in the well-drained areas. Mosses comprised a significant part of the evaporative flux to the atmosphere $\left(22 \mathrm{~mm} \mathrm{yr}^{-1}\right)$. Modeled annual ET was correlated with net primary production, but not with temperature or precipitation; ET and its components were consistent with previous field and modeling studies. Wildfire is driving significant changes in hydrological processes by affecting mean stand age, forest species, and energy balance. These changes, particularly in poorly drained areas, may control the future carbon balance of the boreal forest.
\end{abstract}

Keywords: black spruce, boreal forest, disturbance, evapotranspiration, modeling, stand age, wildfire

Received 22 April 2008; revised version received 3 October 2008 and accepted 20 October 2008

\section{Introduction}

Significant changes in disturbance regimes have occurred for decades in the global boreal forest (Flannigan \& Van Wagner, 1991; Kasischke \& Turetsky, 2006), and future changes in boreal climate, $\mathrm{CO}_{2}$, and fire are likely to be large (Flannigan et al., 2005). Given the large area and high carbon (C) storage of the global boreal forest (Flannigan \& Van Wagner, 1991; Apps et al., 1993; Gower et al., 2001), understanding and predicting its responses to these factors is of great importance. A crucial part of this response will depend on how fire

Correspondence: Ben Bond-Lamberty, tel. + 1301314 6759, fax

+ 1301314 6760, e-mail: bondlamberty@pnl.gov

(C) 2009 Battelle Memorial Institute

Journal compilation (C) 2009 Blackwell Publishing Ltd disturbance and the hydrological cycle interact, particularly because so much of the boreal forest is poorly drained (National Wetlands Working Group, 1988). These areas sequester large amounts of $C$ in peat, and the degree of their vulnerability to changes in climate, hydrology, and fire will influence regional biogeochemical cycles (Camill et al., 2001).

Wildfire is the primary disturbance agent in most of the boreal forest (Stocks, 1991), and an important driver of ecosystem dynamics at both local and regional scales (Chambers \& Chapin, 2002). The area burned by wildfire in central Canada has increased in recent decades (Stocks et al., 2003), and modeling studies suggest that late 20th-century $C$ balance was driven primarily by changes in the fire regime (Balshi et al., 
2007; Bond-Lamberty et al., 2007b). In central Canada, late 20th-century increases in fire has meant the conversion of large areas of mature evergreen needleleaf conifers (primarily Picea mariana) to stands dominated by young deciduous broadleafs (primarily Populus tremuloides), with significant consequences for regional $\mathrm{C}$, nutrient, and water dynamics (Bond-Lamberty et al., 2007b).

The effects of changing climate and disturbance on evapotranspiration (ET) and forest water cycling are not well understood. Human influences are changing ET in the northern hemisphere (Fernandes et al., 2007), while at a smaller scale fire clearly affects stand water cycling (Ewers et al., 2005; Amiro et al., 2006a), watershedscale hydrology (Valeo et al., 2003), and regional climate (Chambers \& Chapin, 2002). In the land-atmosphere water flux, ET is closely coupled with net primary production (NPP) through plant stomatal controls on transpiration (Campbell \& Norman, 1998; Tang et al., 2006); if ET changes with disturbance, this will have important implications for local, regional, and continental growth and climate dynamics. Increased fire and $\mathrm{CO}_{2}$ are correlated (Flannigan et al., 2005), and rising $\mathrm{CO}_{2}$ may reduce ET and thus latent heat flux from the landscape, exacerbating regional climate change (Sellers et al., 1996; Gedney et al., 2006; Betts et al., 2007).

Low temperatures and nitrogen availability constrain ET in the boreal forest (Baldocchi et al., 2000; Ewers et al., 2001), and boreal water vapor fluxes at the stand level vary with species composition (Linder \& Troeng, 1980; Baldocchi et al., 1997; Jarvis et al., 1997), structural changes with stand age (Ewers et al., 2005; Amiro et al., 2006a, b), permafrost changes (Camill et al., 2001), and soil drainage (Lafleur et al., 1997) among other factors. The boreal tree canopy is dominated by relatively few species, predominantly evergreen needleleaf conifers, but mosses form a significant part of the C, nitrogen, and water cycles in many boreal forests (Skre \& Oechel, 1981; Longton, 1992; Heijmans et al., 2004; Suzuki et al., 2007). The water dynamics of such bryophytes are not as well quantified as those of vascular plants, and are rarely modeled (Sonnentag et al., 2008).

The goals of this study were to use Biome-BGC, a well-known ecophysiological model, to simulate the effects of changing wildfire on a subset of hydrological processes in the central Canadian boreal forest. Specifically, we examined the following questions: (i) what was the effect of changing fire on ET and its components in the last half-century? (ii) Given that the model predicts changes in dominance among the three vegetation types - coniferous trees, deciduous broadleaf trees, and mosses - that were simulated over this time period (Bond-Lamberty et al., 2007b), what are the consequences for regional ET fluxes?

\section{Material and methods}

\section{Simulation area}

The region simulated was the BOREAS study region (Sellers et al., 1995), a $1000 \mathrm{~km} \times 1000 \mathrm{~km}$ bounded by the points $\left(60.0^{\circ} \mathrm{N},-111.0^{\circ} \mathrm{W}\right),\left(58.8^{\circ} \mathrm{N},-93.5^{\circ} \mathrm{W}\right)$, $\left(50.1^{\circ} \mathrm{N},-97.0^{\circ} \mathrm{W}\right)$, and $\left(51.0^{\circ} \mathrm{N},-111.0^{\circ} \mathrm{W}\right)$. At 100 million ha, and comprising $6-8 \%$ of the global boreal forest and 15-20\% of the North American boreal forest, it encompasses much of Manitoba and Saskatchewan as well as eastern Alberta, with Lake Winnipeg in the southeast, Hudson Bay in the northeast, and Lake Athabasca in the northwest (Fig. 1). Terrain is flat to gently rolling, with elevations $\sim 250 \mathrm{~m}$ in the northeast and $\sim 500 \mathrm{~m}$ in the southwest; species diversity is low and the forest is dominated by black spruce [P. mariana (Mill.) BSP], trembling aspen (P. tremuloides Michx.), and jack pine (Pinus banksiana Lamb.), with almost continuous bryophyte coverage (feathermosses and Sphagnum spp.) in the understory. From aspen parkland and mixedwoods in its south to black spruce-dominated boreal forest in the center to the forest-tundra transition in its north, this grid encompassed a wide cross-section of the boreal forest biome.

\section{The Biome-BGC model}

The processes and logic of Biome-BGC have been discussed in detail in many publications (Running \& Coughlan, 1988; Running \& Gower, 1991; Kimball et al., 1997a; Bond-Lamberty et al., 2005a) and we present only a short summary here. Biome-BGC runs on a daily time step, using daily meteorological data, ecophysiological parameters, and general stand soil information to simulate energy, C, water, and nitrogen cycling (Running \& Hunt, 1993; White et al., 2000). Ecophysiological parameters define vegetation types descriptions based on leaf habit, photosynthesis pathway, plant type, etc. - that are intended to be broadly significant. The version of Biome-BGC used here was based on the 4.1.2 version but extensively modified. These changes allowed Biome-BGC to more accurately simulate boreal soil temperatures (Bond-Lamberty et al., $2005 b)$, account for the deleterious effects of poor soil drainage on soil decomposition and vascular plant growth, and simulate bryophyte growth (Bond-Lamberty et al., 2007a). This version also simulated multiple vegetation types concurrently, allowing for forest succession (Bond-Lamberty et al., 2005a).

There are two ways in which water can enter a Biome-BGC simulation in our revised version of the model, via soil inflow and precipitation, and six ways in which it can exit: soil outflow, soil evaporation, snow 


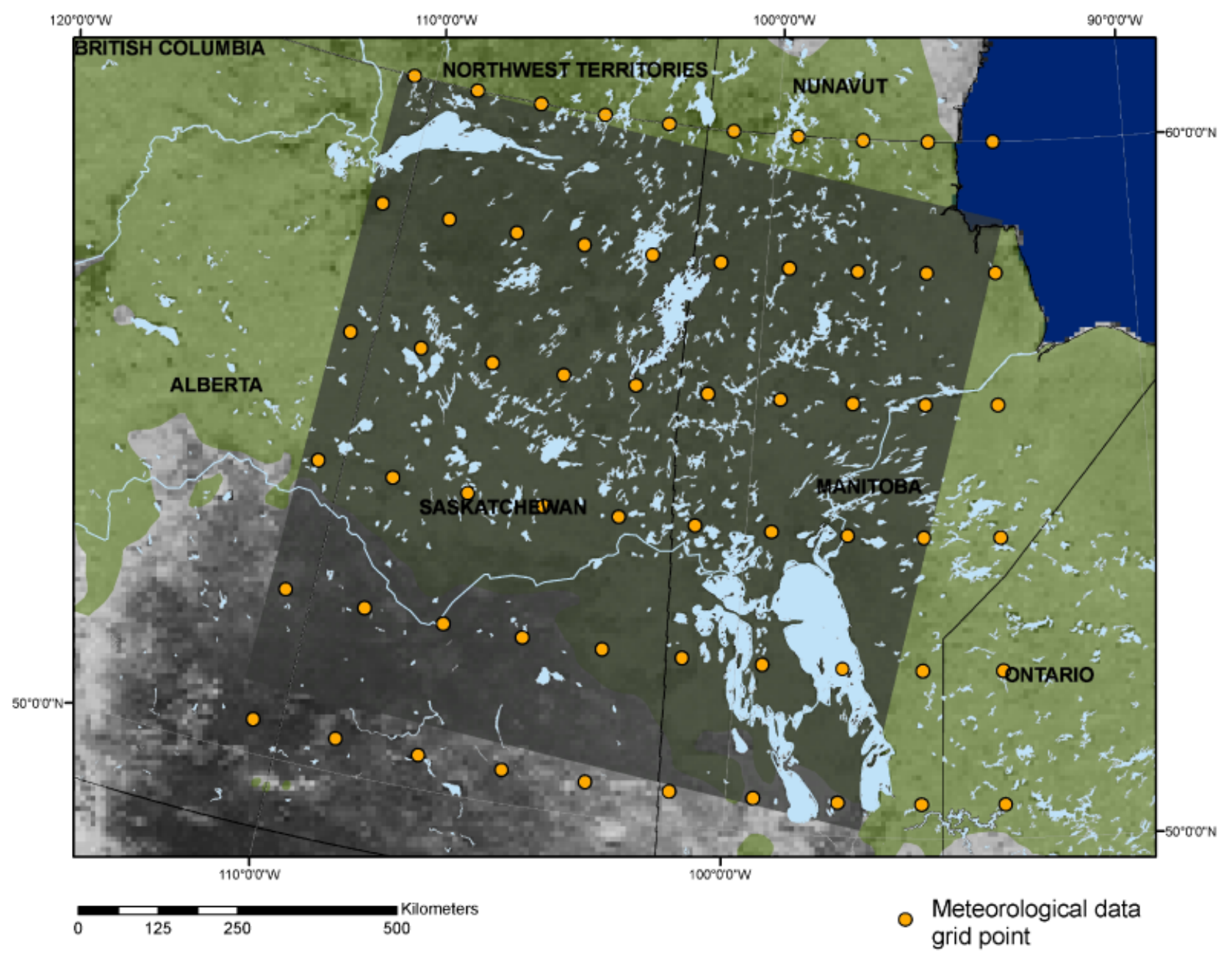

Fig. 1 The BOREAS grid $(1000 \mathrm{~km} \times 1000 \mathrm{~km})$ simulated in this study, with yellow dots showing NCAR meteorological data points.

sublimation, canopy evaporation, canopy transpiration, and volatilization in fire. A fraction of precipitation is intercepted by the plant canopy and subject to evaporation before transpiration occurs. Soil evaporation and canopy ET are determined using the Penman-Monteith equation (Monteith, 1965; Campbell \& Norman, 1998) and thus driven primarily by radiation and vapor pressure deficit. Leaf and canopy conductances are determined by stomatal, cuticular and boundary layer conductances (the first two in parallel, the last in series), defined on a vegetation-specific basis and modulated by plant water stress, temperature, vapor pressure deficit and soil anoxia (Thornton, 1998; Bond-Lamberty et al., 2007a). All vegetation types being simulated have the potential to contribute to total transpiration, although in the current study moss conductance was set to zero (see the following text) and thus its effect was only via canopy evaporation and shading of the soil surface.

\section{Sources of input data: land cover and soils}

Forested vs. nonforested land cover categories were determined using the IGBP landcover classification of the MODIS landcover product for 2004 (MOD12Q1, http://www-modis.bu.edu/landcover/userguidelc/lc. $\mathrm{html}$ ). If the native projection of these (and any other) data was not the BOREAS Albers Equal Area Conic (BOREAS AEAC), then the data were reprojected. MODIS products were imported, subset, reprojected to the AEAC, and masked to include only the simulation grid; nearest neighbor resampling was used for land cover.

Soil data were derived from data layers of the BOREAS regional soils data in raster format (http:// daac.ornl.gov/BOREAS/guides/Region_Soils_Raster. $\mathrm{html}$ ). Estimates of the sand, silt, and clay percentages were obtained using the soil texture raster data and the Canadian Soil Information System (CanSIS) website 
Table 1 Summary of meteorological forcing data, by grid quadrant (northwest, northeast, southwest, southeast) for years $1948-2005$

\begin{tabular}{|c|c|c|c|c|c|c|c|c|}
\hline \multirow[b]{2}{*}{ Quadrant } & \multicolumn{2}{|c|}{ Precipitation } & \multicolumn{2}{|c|}{$T_{\mathrm{AVG}}\left({ }^{\circ} \mathrm{C}\right)$} & \multicolumn{2}{|c|}{$T_{\mathrm{MIN}}\left({ }^{\circ} \mathrm{C}\right)$} & \multicolumn{2}{|c|}{$T_{\text {MAX }}\left({ }^{\circ} \mathrm{C}\right)$} \\
\hline & Mean* & Trend & Mean & Trend & Mean $\dagger$ & Trend & Mean & Trend \\
\hline NW & 0.20 & -0.01 & -1.21 & 0.05 & -7.39 & 0.10 & 1.94 & 0.03 \\
\hline $\mathrm{NE}$ & 0.17 & -0.01 & -2.95 & 0.03 & -9.00 & 0.10 & 0.21 & 0.00 \\
\hline SW & 0.17 & 0.00 & 3.20 & -0.07 & -3.60 & 0.05 & 6.68 & -0.13 \\
\hline SE & 0.19 & 0.00 & 2.35 & -0.06 & -4.19 & 0.04 & 5.76 & -0.12 \\
\hline All & 0.18 & 0.00 & 0.35 & -0.01 & -6.05 & 0.07 & 3.65 & -0.06 \\
\hline
\end{tabular}

Mean ( $N=100$ met data points; cf. Fig. 1$)$ and trend (per 10 years) data are shown for precipitation $\left(\mathrm{cm} \mathrm{day}^{-1}\right)$, and mean annual daily mean, minimum, and maximum temperatures $\left(T_{\mathrm{AVG}}, T_{\mathrm{MIN}}\right.$, and $T_{\mathrm{MAX}}$, respectively; $\left.{ }^{\circ} \mathrm{C}\right)$. Significant trends $(P<0.05$ in a simple linear model) are in bold.

*Standard errors (based on annual means) were $0.02-0.03 \mathrm{~mm}, 0.91-1.02{ }^{\circ} \mathrm{C}, 1.10-1.21{ }^{\circ} \mathrm{C}$, and $0.98-1.09{ }^{\circ} \mathrm{C}$, respectively.

$\dagger$ For 1948-2005, mean annual number of days with $T_{\mathrm{MIN}}>0{ }^{\circ} \mathrm{C}$ was 143, 148, 231, and 228 for NW, NE, SW, and SE quadrants, respectively; trends (per 10 years) were $0.1,1.0,0.6$, and 1.0 .

(http://sis.agr.gc.ca/cansis/); these were applied to all other soils in the raster image that were similar to known soil textures. Thirty percent of the BOREAS grid was coded as 'not applicable'. To increase the number of pixels with soil texture information, these 'not applicable' locations were filled in by association with land cover. The rooting depth data layer was used to calculate the Biome-BGC effective soil depth parameter, based on four categories $(0.2,0.75,1.5$, and $2.5 \mathrm{~m})$.

A digital elevation model, obtained from the ORNL DAAC, had a spatial resolution of $1 \mathrm{~km}$ and elevations estimated to the nearest meter. The MODIS MCD43B product (http://www-modis.bu.edu/brdf/userguide/ param.html) was used for albedo. A 16-day composite image from July 28 to August 12, 2003, was calibrated and resampled using bilinear interpolation, and the shortwave band extracted from the 20-band image. A soil drainage class raster image was used to compute water inflow and outflow rate parameters (inflow $\alpha_{0}$, surface outflow $\alpha_{1}$, and subsurface outflow $\alpha_{2}$ ) (BondLamberty et al., 2007a) based on the following criteria: excessively well drained $\left(\alpha_{0}=0.0, \alpha_{1}=1.0, \alpha_{2}=0.8\right)$; well to moderately well drained $\left(\alpha_{0}=0.0, \alpha_{1}=1.0, \alpha_{2}=\right.$ $0.5)$; poorly drained $\left(\alpha_{0}=0.5, \alpha_{1}=0.1, \alpha_{2}=0.01\right)$; very poorly drained $\left(\alpha_{0}=1.0, \alpha_{1}=0.01, \alpha_{2}=0.0\right)$.

\section{Sources of input data: meteorology and fire}

Meteorological data were downloaded from the Climate Analysis Branch at NOAA (http://www.cdc.noaa.gov/ cdc/reanalysis/reanalysis.shtml) for 1948-2005. These data included maximum daily temperature, minimum daily temperature, specific humidity, shortwave radiation, surface pressure, and precipitation rate, and were on the T1 Gaussian grid. A subset of the global grid was chosen to adequately cover the study area, and the data resampled to the simulation grid, with $20 \mathrm{~km}$ resolution using weighted distance interpolation with the six nearest latitude/longitude points (Fig. 1). Vapor pressure deficit was calculated from surface pressure and specific humidity (Campbell \& Norman, 1998). Meteorology input data are summarized in Table 1.

Spatially and temporally explicit data from the Canadian Forest Service's Large Fire Database (LFDB) were used to drive the model; these data include $97 \%$ of the area burned in Canada (Stocks et al., 2003). The LFDB covers 1959-2005; data for 1948-1958 were derived based on provincial records of total area burned and the known fire size distributions data of the LFDB. Mean area burned in the study area was $122773 \mathrm{ha} \mathrm{yr}^{-1}$

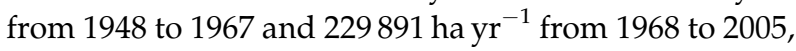
an $87 \%$ increase. The Biome-BGC disturbance mechanism used here was developed by the Forest Ecosystem Ecology Laboratory at the University of WisconsinMadison. Fire events (of constant intensity and length of 1 day) occurred spatially following to the LFDB and on a random day of the growing season. In each fire event, $10 \%, 90 \%, 5 \%, 10 \%, 80 \%, 40 \%$, and $10 \%$ of $\mathrm{C}$ was volatilized from stem, leaf, coarse root, fine root, litter, woody debris, and shallow soil, respectively (cf. Albini \& Reinhardt, 1995; Arora \& Boer, 2005; Neff et al., 2005), with the balance going to woody debris (for stems and roots), litter (for leaves), or remaining unaffected (for soil). In addition, $90 \%$ of mineral soil nitrogen was volatilized. Plant growth was restarted the year following fire. Plant physiological parameters for each functional group were standardized across the entire simulation grid (i.e., did not vary spatially). We used the values given by BondLamberty et al. (2006); a summary of these parameters is given in Table 2 . 
Table 2 Summary of physiological parameters used in simulations, by vegetation type

\begin{tabular}{|c|c|c|c|}
\hline Parameter & Spruce & Aspen & Bryophyte \\
\hline Fine root: leaf $C$ & 1.6 & 1.5 & 0.05 \\
\hline Stem C: leaf C & 2.3 & 2.0 & $\mathrm{n} / \mathrm{a}$ \\
\hline Live: total wood C & 0.1 & 0.1 & $\mathrm{n} / \mathrm{a}$ \\
\hline Coarse root: stem $\mathrm{C}$ & 0.3 & 0.4 & $\mathrm{n} / \mathrm{a}$ \\
\hline Leaf $C: N$ & 59.6 & 19.8 & 40.0 \\
\hline Leaf litter $C: N$ & 90.0 & 34.6 & 87.0 \\
\hline Fine $\operatorname{root} \mathrm{C}: \mathrm{N}$ & 60.0 & 19.8 & 40.0 \\
\hline $\begin{array}{l}\text { SLA (projected area basis, } \\
\qquad \mathrm{m}^{2} \mathrm{~kg}^{-1} \mathrm{C} \text { ) }\end{array}$ & 8.3 & 38.7 & 20.0 \\
\hline All sided:projected leaf area & 3.1 & 2.0 & 2.0 \\
\hline Leaf $\mathrm{N}$ in Rubisco $(\%)$ & 6.0 & 14.0 & 6.0 \\
\hline $\begin{array}{l}\text { Max stomatal conductance } \\
\qquad\left(g_{\mathrm{s}}, \mathrm{mm} \mathrm{s}^{-1}\right)\end{array}$ & 3.0 & 5.0 & 0.0 \\
\hline Cuticular conductance $\left(\mathrm{mm} \mathrm{s}^{-1}\right)$ & 0.01 & 0.01 & 0.03 \\
\hline $\begin{array}{l}\text { Boundary layer conductance } \\
\qquad\left(\mathrm{mm} \mathrm{s}^{-1}\right)\end{array}$ & 80.0 & 20.0 & 50.0 \\
\hline$\Psi_{\mathrm{L}}$ start of $g_{\mathrm{s}}$ reduction $(\mathrm{MPa})$ & -0.5 & -0.5 & $\mathrm{n} / \mathrm{a}$ \\
\hline$\Psi_{\mathrm{L}}$ complete $g_{\mathrm{s}}$ reduction $(\mathrm{MPa})$ & -1.7 & -2.3 & $\mathrm{n} / \mathrm{a}$ \\
\hline VPD start of $g_{\mathrm{s}}$ reduction $(\mathrm{kPa})$ & 1.0 & 1.0 & $\mathrm{n} / \mathrm{a}$ \\
\hline $\begin{array}{l}\text { VPD complete } g_{\text {s }} \text { reduction } \\
\qquad(\mathrm{kPa})\end{array}$ & 4.1 & 4.0 & $\mathrm{n} / \mathrm{a}$ \\
\hline Flooded $g_{\mathrm{s}}$ reduction $(\%)$ & 30 & 20 & $\mathrm{n} / \mathrm{a}$ \\
\hline $\begin{array}{l}\text { Days to reach } g_{\text {s }} \text { reduction } \\
\text { (days) }\end{array}$ & 5 & 5 & $\mathrm{n} / \mathrm{a}$ \\
\hline $\begin{array}{l}\text { Full turgor water content } \\
\qquad\left(\mathrm{H}_{2} \mathrm{O}: \mathrm{C}\right)\end{array}$ & $\mathrm{n} / \mathrm{a}$ & $\mathrm{n} / \mathrm{a}$ & 5.0 \\
\hline External water $(\%)$ & $\mathrm{n} / \mathrm{a}$ & $\mathrm{n} / \mathrm{a}$ & 50 \\
\hline
\end{tabular}

Full data and sources can be found in Bond-Lamberty et al. (2006).

\section{Simulation procedures}

The simulation grid was $10^{6} \mathrm{~km}^{2}$; simulation cell size was $1 \mathrm{~km}^{2}$. Each grid cell was independently spun up under historical conditions, using the parameters in Tables 1 and 2 and with a fire return interval of 175 years, until just before its deep soil $C$ stabilized (i.e., leaving a small ongoing $C$ sink) (Pietsch \& Hasenauer, 2006). From this point, two 58-year simulations were performed: one in which disturbance remained at 19481967 levels (scenario 'MC', i.e., meteorology plus climate), and one in which it followed historical records throughout the simulation (scenario ' $M{ }^{2}$ ', i.e., meteorology plus climate plus disturbance). In both scenarios, climate and $\mathrm{CO}_{2}$ followed their historical records (cf. Bond-Lamberty et al., 2007b). All simulations were performed on a distributed computing grid. Sixty desktop computers in a public computer laboratory at the University of Wisconsin-Madison constituted the grid's core; Apple Computer's Xgrid ${ }^{\mathrm{TM}}$ software (Apple Computer, Cupertino, CA, USA) handled job distribution and processing, while custom shell and IDL (ITT Visual Information Solutions, Boulder, $\mathrm{CO}$ ) scripts were used for pre- and postprocessing of data. Statistical analyses were conducted using $\mathrm{R}$ version 2.6.0 ( $\mathrm{R}$ Development Core Team, 2007).

\section{Results}

Increases in wildfire after 1970 had strong effects on ET and its components (Fig. 2). ET averaged $323 \pm 30 \mathrm{~mm} \mathrm{yr}^{-1}$ over the entire simulation (the entire modeling domain in space and time; error term is interannual standard deviation), and was $1.4 \%$ lower in the real-world ' $M D C^{\prime}$ 'scenario relative to the ' $M C^{\prime}$ control scenario; over the last 10 years of the simulation, however, this difference was $3.9 \%$ (Fig. 2a). Increased wildfire resulted in increased soil evaporation $(+13 \%$ from 1996 to 2005), as more sunlight reached the surface in newly burned stands, but lower canopy evaporation and transpiration $(-17 \%$ and $-12 \%$ over the same time period, respectively; Fig. 2b) as leaf area was reduced by fire.

Across the region, canopy transpiration $\left(E_{\mathrm{C}}, 140 \pm\right.$ $\left.11 \mathrm{~mm} \mathrm{yr}^{-1}\right)$ and evaporation from the soil surface $\left(E_{\mathrm{S}}\right.$, $\left.139 \pm 21 \mathrm{~mm} \mathrm{yr}^{-1}\right)$ comprised the largest percentage of total ET (Table 3). Evaporation from the canopy $\left(E_{\mathrm{R}}\right)$ comprised $14-17 \%$ of ET, $44 \mathrm{~mm} \mathrm{yr}^{-1}$, and decreased in the real-world MDC scenario as mature stands with high leaf area burned preferentially. Conifers dominated the $E_{\mathrm{C}}$ flux ( $120 \mathrm{~mm} \mathrm{yr}^{-1}$ in the real-world MDC scenario); transpiration from deciduous trees and bryophytes comprised similar percentages of ET. Fire, as noted above, sharply increased the evaporative flux from the soil surface to the atmosphere (Table 3). In contrast, conifers and bryophytes together dominated the $E_{\mathrm{R}}$ flux, the latter due to their ectohydric nature (ability to carry water external to the plant); each comprised $49 \%$ of the $E_{\mathrm{R}}$ flux $\left(\sim 22 \mathrm{~mm} \mathrm{yr}^{-1}\right)$ in both scenarios (data not shown).

The spatial distribution of changes in the ET flux between the low- (MC) and high-fire (MDC) scenarios is shown in Fig. 3. The depressing effects of fire on ET are clearly visible in the fire scars (circles) running from northwest to southeast across the BOREAS study region. Well-drained areas had higher ET than poorly drained areas in the model, due to higher $E_{\mathrm{C}}(56 \pm$ $5 \mathrm{~mm} \mathrm{yr}^{-1}$ vs. $\left.29 \pm 3 \mathrm{~mm} \mathrm{yr}^{-1}\right), E_{\mathrm{R}}\left(15 \pm 2 \mathrm{~mm} \mathrm{yr}^{-1}\right)$, and $E_{\mathrm{S}}\left(139 \pm 21 \mathrm{~mm} \mathrm{day}^{-1}\right)$ fluxes did not vary by soil drainage class.

The driver behind changes in $E_{C}$ was the shift in species due to fire conversion of mature evergreen conifers to young broadleaf deciduous stands (Fig. 4). Transpiration by evergreen conifers, deciduous broadleafs, and mosses changed by $-25,9$, and $-2 \mathrm{~mm} \mathrm{yr}^{-1}$, respectively, due to changing fire regimes. For 1995- 

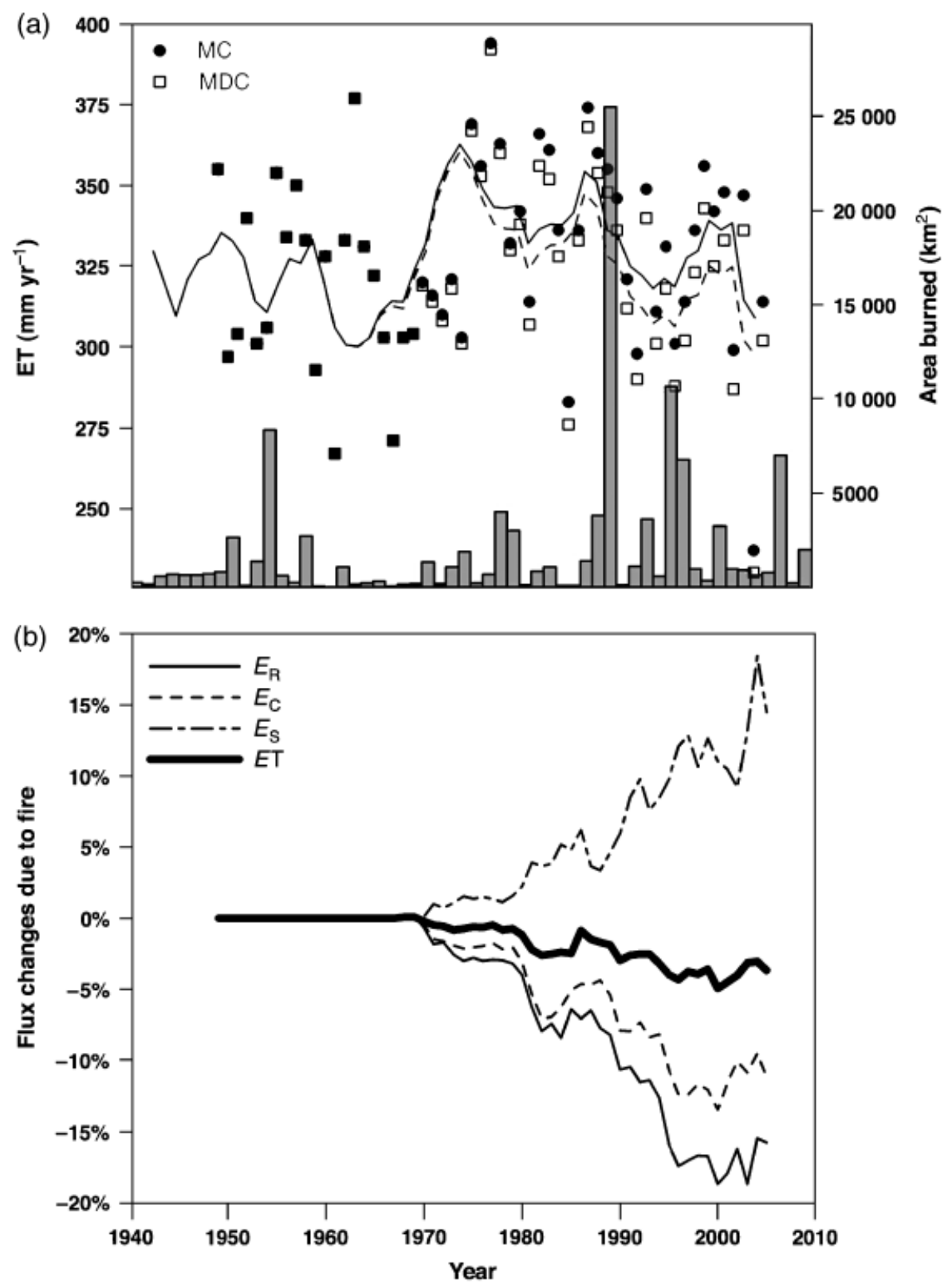

Fig. 2 Effects of fire regimes changes on evapotranspiration (ET) and its components over the course of the simulation. (a) Mean daily ET under the mid-20th-century (MC) and actual historical (MDC) fire regimes; lines (solid line for MC, dashed for MDC) show the 5-year running mean. The bar graph (right-hand axis) shows area burned in the study area. (b) Change in ET and its components (canopy evaporation $E_{\mathrm{R}}$, plant transpiration $E_{\mathrm{C}}$, and soil evaporation $E_{\mathrm{S}}$ ) in the historical MDC scenario relative to the mid-20th-century MC scenario.

2005, for the final 10 years of the simulation, this represented $E_{\mathrm{C}}$ changes of $-18 \%, 148 \%$, and $-18 \%$ of the prefire values for each vegetation type, respectively (Table 3).

The components of modeled annual ET tended to be strongly correlated with temperature $\left(T_{\mathrm{AVG}}\right)$, precipitation, and NPP (Fig. 5). Significant relationships in Fig. 5 were those between $E_{\mathrm{R}}$ and all three variables (for $T_{\mathrm{AVG}}$ and NPP, $R^{2}=0.13$; for precipitation, $F_{1,56}=48.18$; $\left.P<0.001 ; R^{2}=0.46\right)$; between $E_{\mathrm{C}}$ and $T_{\mathrm{AVG}}\left(F_{1,56}=\right.$ 9.27; $\left.P=0.004 ; R^{2}=0.14\right)$; between $E_{\mathrm{S}}$ and precipitation $\left(F_{1,56}=4.62 ; P=0.036 ; R^{2}=0.08\right) ;$ and between total ET and NPP $\left(F_{1,56}=4.63 ; P=0.036 ; R^{2}=0.15\right.$; not shown $)$. The large interannual variability of precipitation and forest growth meant that $R^{2}$ values tended to be low, even for these significant correlations. 
Table 3 Components of total evapotranspiration (ET) as a percentage of the total ET flux, by simulation scenario (MC, mid-20th-century fire data and MDC, historical data)

\begin{tabular}{lllllll}
\hline & & \multicolumn{5}{c}{$E_{\mathrm{C}}$ percentage of ET (\%) } \\
\cline { 5 - 7 } Scenario & $E_{\mathrm{R}}(\%)$ & $E_{\mathrm{S}}(\%)$ & Total & ENF & DBF & BRY \\
\hline 1968-2005 & & & & & & \\
MC & 15 & 39 & 46 & 41 & 3 & 3 \\
MDC & 14 & 42 & 45 & 38 & 4 & 2 \\
1996-2005 & & & & & & \\
MC & 17 & 36 & 47 & 42 & 2 & 3 \\
MDC & 15 & 42 & 43 & 35 & 5 & 3 \\
\hline
\end{tabular}

Canopy evaporation $\left(E_{\mathrm{R}}\right)$, soil evaporation $\left(E_{\mathrm{S}}\right)$, and canopy transpiration $\left(E_{\mathrm{C}}\right)$ are shown; $E_{\mathrm{C}}$ is broken out by vegetation type (ENF, evergreen needleleaf; DBF, deciduous broadleaf; BRY, bryophytes).

\section{Discussion}

Comparison with field data: trees and mosses

Boreal forest ET has been measured at 1.5-2.0 $\mathrm{mm} \mathrm{day}^{-1}$ during the growing season (Lafleur, 1992; Grelle et al., 1997; Jarvis et al., 1997; Kelliher et al., 1997; Amiro et al., 2006a), implying $\sim 250 \mathrm{~mm} \mathrm{yr}^{-1}$ over the year if one assumes a 100-day shoulder season flux of $0.75 \mathrm{~mm} \mathrm{day}^{-1}$ and winter flux of $0.15 \mathrm{~mm}$ day $^{-1}$. Arain et al. (2003) measured ET for 2 years in a black spruce forest in northern Saskatchewan, Canada, and reported a maximum ET of $3.5 \mathrm{~mm}^{-1 a y}{ }^{-1}$, winter fluxes of $0.1-$ $0.25 \mathrm{~mm} \mathrm{day}^{-1}$, and a 2-year mean of $356 \mathrm{~mm} \mathrm{yr}^{-1}$, compared with the mean value of $323 \mathrm{~mm} \mathrm{yr}^{-1}$ reported here. A comparison of model results against a range of eddy covariance data from across western Canada is shown in Fig. 6; the mean and variability of ET simulated here broadly matches the mean and range of these published data.
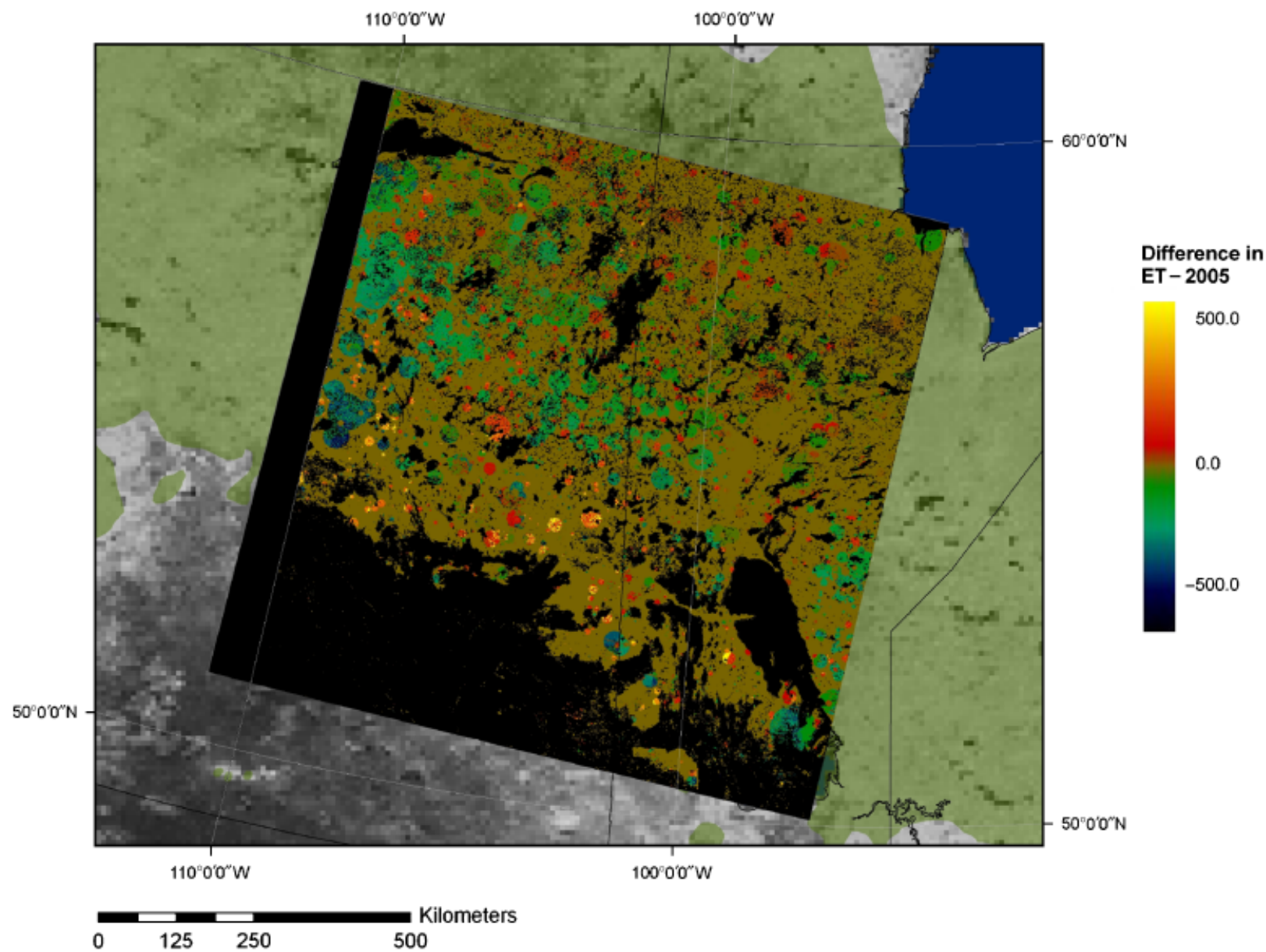

Fig. 3 Effect of changing fire regime on simulated evapotranspiration (ET) at the regional scale. Colors indicate difference in mean daily ET $\left(\mathrm{mm} \mathrm{yr}^{-1}\right)$ between the historical and mid-20th-century scenarios. Data are from 1996 to 2005 model output.

(C) 2009 Battelle Memorial Institute

Journal compilation (C) 2009 Blackwell Publishing Ltd, Global Change Biology, doi: 10.1111/j.1365-2486.2008.01776.x 

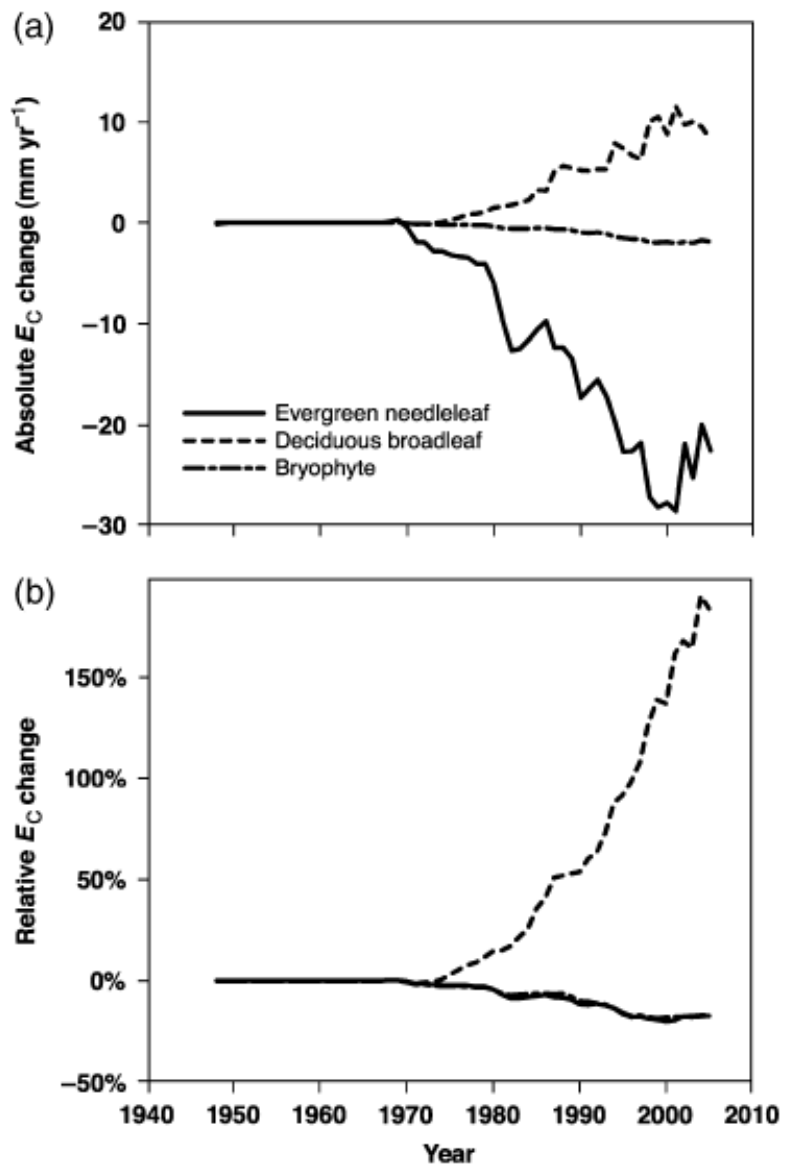

Fig. 4 Absolute (a) and relative (b) changes in canopy transpiration $\left(E_{\mathrm{C}}\right)$ under actual fire regimes, relative to the mid-20thcentury regime, by vegetation type and year.

In the results here, $E_{C}$ was dominated by evergreen conifers, but the conifers' contribution was subject to large changes with stand age and fire. Ewers et al. (2005) used Granier sapflux sensors to calculate growing season $E_{C}$ values of $0.1-3.3 \mathrm{~mm}$ day $^{-1}$ for a boreal black spruce chronosequence; broadleaf $P$. tremuloides accounted for from $33 \%$ of $E_{\mathrm{C}}$ (in the youngest, 12-yearold stand) to $0 \%$ (in the oldest stands) of $E_{\mathrm{C}}$, implying a chronosequence average value of $\sim 3 \%$. The results of this study are similar to those of Ewers et al. (2005), as broadleaf trees accounted for $4-5 \%$ of $E_{C}$ at the regional scale here. Grelle et al. (1997) found that $E_{\mathrm{C}}, E_{\mathrm{R}}$, and $E_{\mathrm{S}}$ comprised $65 \%, 20 \%$, and $15 \%$ of total ET in a Swedish pine/spruce forest; the corresponding percentages in this simulation were $43 \%, 15 \%$, and $42 \%$, that is, soil evaporation comprised a larger percentage of ET, and canopy transpiration a small percentage, than in the 100-year-old stand measured by Grelle et al. (1997). This is reasonable, as our regional-level results included many recently burned stands with high $E_{S}$.

The effect of soil drainage in the model was expressed through differences in $E_{\mathrm{C}}$, as neither $E_{\mathrm{R}}$ nor $E_{\mathrm{S}}$ varied by drainage. The higher $E_{C}$ and ET simulated here is consistent with energy balance data from a black spruce chronosequence in Manitoba (B. Amiro, University of Manitoba, unpublished data), but there have been few other studies of paired stands. Bogs and other poorly drained areas are dominated by mosses, which play an important role in cycling of water in boreal forests (Skre \& Oechel, 1981; Longton, 1992; Price et al., 1997; Heijmans et al., 2004), but because their physiological controls on water use differ radically from those of vascular plants (Proctor, 2000), they have rarely been modeled as plants per se (Zhang et al., 2002; BondLamberty et al., 2007a). Heijmans et al. (2004) reported moss evaporation rates of $0.3-1.5 \mathrm{~mm} \mathrm{day}^{-1}$ in an Alaskan boreal forest during the growing season, corresponding roughly to $40-160 \mathrm{~mm} \mathrm{yr}^{-1}$ on an annual basis (assuming shoulder season and winter fluxes of 0.1 and $0.0 \mathrm{~mm} \mathrm{day}^{-1}$, respectively). Simulated bryophyte water flux at a regional level averaged $22 \mathrm{~mm} \mathrm{yr}^{-1}$ in this study; assuming poorly drained areas comprise about one-third of the landscape (National Wetlands Working Group, 1988), this results compares well with the results of Heijmans et al. (2004).

\section{Comparison with large-scale modeling studies}

Few large-scale modeling studies of the hydrologic cycle have been performed for the boreal forest. Kang et al. (2006) used Biome-BGC to model $357500 \mathrm{~km}^{2}$ in the BOREAS region from 1959 to 1996, and examined the effects of changing $\mathrm{CO}_{2}$, climate, and fire on NPP and ET. Their results are particularly appropriate to discuss here, as their study overlaps with ours in geographic area, time span studied, and model used. Kang et al. (2006) found that (i) ET was most sensitive to precipitation changes, and (ii) fire decreased ET by 9-38\%, depending on forest type, while increasing soil evaporation. We found that ET was not significantly correlated with precipitation, in contrast to finding (i) by Kang et al. (2006), with the primary driver of this sensitivity being the correlations between $E_{\mathrm{R}}$ and $E_{\mathrm{S}}$ with precipitation; the correlation with transpiration was not significant, although precipitation was significantly correlated with both $E_{\mathrm{S}}$ and $E_{\mathrm{R}}$. This is unsurprising as water is probably not a limiting factor for plant growth in these systems. Our finding that fire increases $E_{S}$ while reducing overall ET was similar to that of Kang et al. (2006), though we observed much smaller decreases. This difference is probably due to the multivegetation model used here, in which a coniferous stand can be quickly replaced after burning by a deciduous stand. The drop in leaf area index (LAI) after fire is relatively transient, and the ET response a balance of decreased $E_{C}$ and increased $E_{S}$; such a response is 


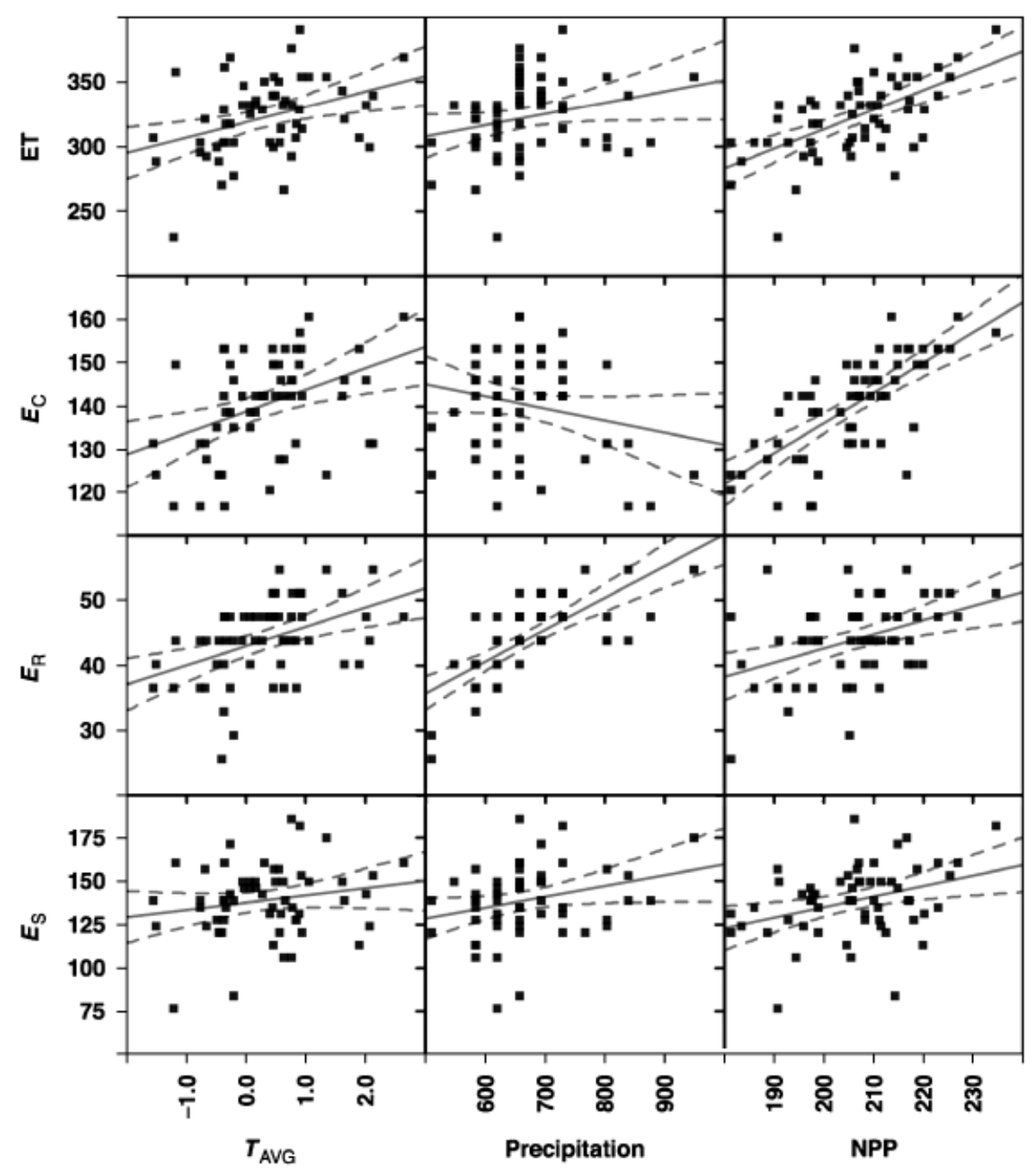

Fig. 5 Relationship of total evapotranspiration (ET), canopy evaporation $\left(E_{\mathrm{R}}\right)$, transpiration $\left(E_{\mathrm{C}}\right)$, and soil evaporation $\left(E_{\mathrm{S}}\right)$ (all in $\left.\mathrm{mm} \mathrm{yr}^{-1}\right)$ to mean annual temperature $\left(T_{\mathrm{AVG}},{ }^{\circ} \mathrm{C}\right)$, precipitation $\left(\mathrm{mm} \mathrm{yr}^{-1}\right)$, and net primary production $\left(\mathrm{NPP} ; \mathrm{gC} \mathrm{m}^{-2} \mathrm{yr}^{-1}\right) . \mathrm{Dotted}$ lines show $95 \%$ confidence intervals.

similar to arguments made for ET homeostasis (Roberts, 1983). In summary, our results are largely consistent with those of Kang et al. (2006).

\section{The ability of Biome-BGC to simulate water fluxes}

Numerous authors have examined the accuracy of the Biome-BGC in simulating boreal ET at a daily time step. In the well-drained BOREAS sites, Kimball et al. (1997b) reported that Biome-BGC explained $62-98 \%$ of the variability in observed daily ET and soil water, with black spruce in the model rarely subject to water stress. Amthor et al. (2001) found that Biome-BGC underpredicted monthly ET for the moderately well-drained BOREAS NSA tower site, ranking in the lower third of the nine models examined. On a daily time step, however, Biome-BGC performed in the top third
(Amthor et al., 2001). Across seven temperate North American evergreen forests, the model had a mixed performance simulating annual ET, greatly underestimating it for a Florida Pinus elliottii plantation (Thornton et al., 2002). Churkina et al. (2003) found that Biome-BGC explained $60-88 \%$ of measured ET variability in four European coniferous forests, while overestimating ET at high fluxes. Pietsch et al. (2003) reported that extending Biome-BGC to allow for groundwater infiltration and flooding - key characteristics of floodplains - greatly improved the model's performance. Similarly, Engstrom et al. (2006) modified the model by adding water storage and nonvascular vegetation evaporation routines, and found that while the original Biome-BGC greatly underestimated ET, their new version slightly overestimated it at well- and poorly drained Arctic tundra sites. 


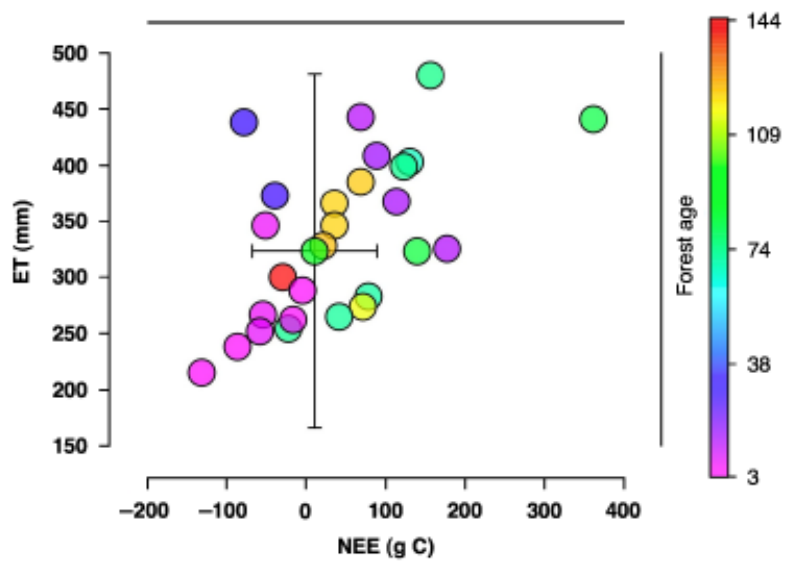

Fig. 6 Annual evapotranspiration (ET) vs. net ecosystem exchange (NEE), simulated and observed data. Most circles show published data from eddy covariance sites in the western Canadian boreal forest (Black et al., 1996; Jarvis et al., 1997; Goulden et al., 1998; Arain et al., 2003; Griffis et al., 2003; Amiro et al., 2006a; Pejam et al., 2006; Sass, 2007). The circle with error bars is the mean simulated ET and NEE over the modeling domain; error bars are spatial variability. Circle fill color indicates forest age.

There are weaknesses in the modeling approach used here. We did not consider the effects of grasses or shrubs, and their contribution to ET flux can be significant in some boreal systems (e.g., Lafleur et al., 1997; Admiral et al., 2006). Biome-BGC includes no explicit energy balance calculation, which simplifies the input parameter requirements but forces a crude calculation of, for example, soil temperatures (Bond-Lamberty et al., 2005b). Finally, Biome-BGC is not designed to simulate poorly drained areas, and its performance in such areas is significantly worse than in well-drained forests (Bond-Lamberty et al., 2006, 2007a). The drivers of ET are considerably different in poorly drained forests (Mackay et al., 2007): we expect a wetland/ peatland forest to be driven by net radiation in the early stages after fire and to become more (but never completely) driven by VPD in the latter stages of succession. This also implies that the drivers of ET will be evaporation from bryophytes and soil early in succession, and tree transpiration later in succession, and that interannual variability of ET will be lower in such areas.

\section{Effects of disturbance on forest water and $C$ fluxes}

Boreal wildfires in central Canada effect species shifts over decadal periods, converting evergreen conifer (typically P. mariana or P. banksiana) stands to broadleaf deciduous ones (P. tremuloides), as well as changing the age structure of the forest (Kurz \& Apps, 1999). In addition, other disturbances such as logging, insects, and pathogens are growing in importance and can have effects comparable in scale to those from fire (Malmström \& Raffa, 2000; Kurz et al., 2008). The resulting change in species and leaf phenology will in turn affect the seasonality of $C$ and water fluxes (Ewers et al., 2005). Even without species changes, a shift in mean stand age may be important: Goulden et al. (1998) concluded that high evaporative demand $(D)$ would have little effect on the gross primary production of a mature black spruce forest, but younger black spruce stands have been shown to be more sensitive to $D$ than older forest (Ewers et al., 2005). With increasing fire, such older stands constitute a shrinking proportion of the forest and thus cannot be taken as representative of the region in which they sit.

These changes also affect the underlying soils. The removal of the dense canopy, and frequently the insulating organic layers, means increased soil evaporation, reduced transpiration and canopy evaporation, and concomitant shifts in the temperature regimes of the soil (Bond-Lamberty et al., 2005b). Water and thick insulating moss and soil layers minimize decomposition in poorly drained boreal areas (Viereck, 1983; Harden et al., 1997); this results in forests with the highest $\mathrm{C}$ density in the world, but also means that such $C$ reservoirs are vulnerable to changes in fire and drainage regimes, although they may currently be damping swings in regional $\mathrm{C}$ balance (Bond-Lamberty et al., 2007b). Changes in hydrological processes may thus control the future $\mathrm{C}$ balance of the boreal forest (Goulden et al., 1998; Barr et al., 2006; Dunn et al., 2006; Krishnan et al., 2006), and as such should be a focus of improvement in ecophysiological models.

\section{Conclusion}

Wildfire is driving significant changes in hydrological processes in the boreal forest, changes that in turn may affect the growth of the forest, its ability to sequester C, and regional climate. This makes understanding the complete forest disturbance history - in the central Canadian boreal forest, fire, insects, and logging critical. In addition, the biotic and abiotic differences between well- and poorly drained areas mean that changing disturbance regimes will affect them quite differently. Ecosystem models that scale across large areas, accurately simulate poorly drained areas, and have been tested against robust ET data from forests of a variety of drainage and stand-age points, will be necessary for the accurate estimation and modeling of boreal hydrological dynamics. 


\section{Acknowledgements}

This research was supported by a grant from the National Science Foundation to B. E. Ewers, S. T. Gower, and B. Amiro (DEB-0515957). Biome-BGC version 4.1.2 was provided by the Numerical Terradynamic Simulation Group (NTSG) at the University of Montana; NTSG assumes no responsibility for the proper use of Biome-BGC by others.

\section{References}

Admiral SW, Lafleur PM, Roulet NT (2006) Controls on latent heat flux and energy partitioning at a peat bog in eastern Canada. Agricultural and Forest Meteorology, 140, 308-321.

Albini FA, Reinhardt ED (1995) Modeling ignition and burning rate of large woody natural fuels. International Journal of Wildland Fire, 5, 81-91.

Amiro BD, Barr AG, Black TA et al. (2006a) Carbon, energy and water fluxes at mature and disturbed forest sites, Saskatchewan, Canada. Agricultural and Forest Meteorology, 136, 237-251.

Amiro BD, Orchansky AL, Barr AG et al. (2006b) The effect of post-fire stand age on the boreal forest energy balance. Agricultural and Forest Meteorology, 140, 41-50.

Amthor JS, Chen JM, Clein JS et al. (2001) Boreal forest $\mathrm{CO}_{2}$ exchange and evapotranspiration predicted by nine ecosystem process models: intermodal comparisons and relationships to field measurements. Journal of Geophysical Research - Atmospheres, 106, 33623-33648.

Apps MJ, Kurz WA, Luxmoore RJ et al. (1993) The changing role of circumpolar boreal forests and tundra in the global carbon cycle. Water, Air, and Soil Pollution, 70, 39-53.

Arain MA, Black TA, Barr AG, Griffis TJ, Morgenstern K, Nesic Z (2003) Year-round observations of the energy and water vapour fluxes above a boreal black spruce forest. Hydrological Processes, 17, 3581-3600.

Arora V, Boer GJ (2005) Fire as an interactive component of dynamic vegetation models. Journal of Geophysical Research, 110, G02008.

Baldocchi DD, Kelliher FM, Black TA, Jarvis PG (2000) Climate and vegetation controls on boreal zone energy exchange. Global Change Biology, 6, 69-83.

Baldocchi DD, Vogel CS, Hall B (1997) Seasonal variation of energy and water vapor exchange rates above and below a boreal jack pine forest canopy. Journal of Geophysical Research Atmospheres, 102, 28939-28951.

Balshi MS, McGuire AD, Zhuang Q et al. (2007) Role of historical fire disturbance in the carbon dynamics of the pan-boreal region: a process-based analysis. Journal of Geophysical Research - Biogeosciences, 112, G02029, doi: 10.1029/2006JG000380.

Barr AG, Black TA, Hogg EH et al. (2006) Climatic controls on the carbon and water balances of a boreal aspen forest, 1994-2003. Global Change Biology, 12, 1-16.

Betts RA, Boucher O, Collins $\mathrm{M}$ et al. (2007) Projected increase in continental runoff due to plant responses to increasing carbon dioxide. Nature, 448, 1037-1041.

Black TA, den Hartog G, Neumann HH et al. (1996) Annual cycles of water vapour and carbon dioxide fluxes in and above a boreal aspen forest. Global Change Biology, 2, 219-229.
Bond-Lamberty B, Gower ST, Ahl DE (2007a) Improved simulation of poorly drained forests using Biome-BGC. Tree Physiology, 27, 703-715.

Bond-Lamberty B, Gower ST, Ahl DE, Thornton PE (2005a) Reimplementation of the BIOME-BGC model to simulate successional change. Tree Physiology, 25, 413-424.

Bond-Lamberty B, Gower ST, Goulden ML, McMillan A (2006) Simulation of boreal black spruce chronosequences: comparison to field measurements and model evaluation. Journal of Geophysical Research - Biogeosciences, 111, G02014, doi: 10.1029/ 2005JG000123.

Bond-Lamberty B, Peckham SD, Ahl DE, Gower ST (2007b) The dominance of fire in determining carbon balance of the central Canadian boreal forest. Nature, 450, 89-92.

Bond-Lamberty B, Wang C, Gower ST (2005b) Spatiotemporal measurement and modeling of boreal forest soil temperatures. Agricultural and Forest Meteorology, 131, 27-40.

Camill P, Lynch JA, Clark JS, Adams JB, Jordan B (2001) Changes in biomass, aboveground net primary production, and peat accumulation following permafrost thaw in the boreal peatlands of Manitoba, Canada. Ecosystems, 4, 461-478.

Campbell GS, Norman JM (1998) An Introduction to Environmental Biophysics. Springer-Verlag, New York.

Chambers SD, Chapin FS (2002) Fire effects on surface-atmosphere energy exchange in Alaskan black spruce ecosystems: implications for feedbacks to regional climate. Journal of Geophysical Research - Atmospheres, 108, 8145, doi: 10.1029/ 2001JD000530.

Churkina G, Tenhunen JD, Thornton PE et al. (2003) Analyzing the ecosystem carbon dynamics of four European coniferous forests using a biogeochemistry model. Ecosystems, 6, 168-184.

Dunn AL, Barford CC, Wofsy SC, Goulden ML, Daube BC (2006) A long-term record of carbon exchange in a boreal black spruce forest: means: responses to interannual variability, and decadal trends. Global Change Biology, 12, 1-14.

Engstrom R, Hope A, Kwon H, Harazono Y, Mano M, Oechel WC (2006) Modeling evapotranspiration in Arctic coastal plain ecosystems using a modified BIOME-BGC model. Journal of Geophysical Research - Biogeosciences, 111, G02021, doi: 10.1029/2005JG000102.

Ewers BE, Gower ST, Bond-Lamberty B, Wang C (2005) Effects of stand age and tree species composition on transpiration and canopy conductance of boreal forest stands. Plant, Cell and Environment, 28, 660-678.

Ewers BE, Oren R, Phillips N, Strömgren M, Linder S (2001) Mean canopy stomatal conductance responses to water and nutrient availabilities in Picea abies and Pinus taeda. Tree Physiology, 21, 841-850.

Fernandes R, Korolevych V, Wang S (2007) Trends in land evapotranspiration over Canada for the period 1960-2000 based on in situ climate observations and a land surface model. Journal of Hydrometeorology, 8, 1016-1030.

Flannigan MD, Logan KA, Amiro BD, Skinner WR, Stocks BJ (2005) Future area burned in Canada. Climatic Change, 72, 1-16.

Flannigan MD, Van Wagner CE (1991) Climate change and wildfire in Canada. Canadian Journal of Forest Research, 21, $66-72$. 
Gedney N, Cox PM, Betts RA, Boucher O, Huntingford C, Stott PA (2006) Detection of a direct carbon dioxide effect in continental river runoff records. Nature, 439, 835-838.

Goulden ML, Wofsy SC, Harden JW et al. (1998) Sensitivity of boreal forest carbon balance to soil thaw. Science, 279, 214-217.

Gower ST, Krankina ON, Olson RJ, Apps MJ, Linder S, Wang C (2001) Net primary production and carbon allocation patterns of boreal forest ecosystems. Ecological Applications, 11, 13951411.

Grelle A, Lundberg A, Lindroth A, Moren AS, Cienciala E (1997) Evaporation components of a boreal forest: variations during the growing season. Journal of Hydrology, 197, 70-87.

Griffis TJ, Black TA, Morgenstern K et al. (2003) Ecophysiological controls on the carbon balances of three southern boreal forests. Agricultural and Forest Meteorology, 117, 53-71.

Harden JW, O'Neill KP, Trumbore SE, Veldhuis H, Stocks BJ (1997) Moss and soil contributions to the annual net carbon flux of a maturing boreal forest. Journal of Geophysical Research, 102, 28805-28816.

Heijmans MMPD, Arp WJ, Chapin FS (2004) Controls on moss evaporation in a boreal black spruce forest. Global Biogeochemical Cycles, 18, GB2004, doi: 10.1029/2003GB002128.

Jarvis PG, Massheder JM, Hale SE, Moncrieff JB, Rayment MB, Scott SL (1997) Seasonal variation of carbon dioxide, water vapor, and energy exchanges of a boreal black spruce forest. Journal of Geophysical Research - Atmospheres, 102, 28953-28966.

Kang S, Kimball JS, Running SW (2006) Simulating effects of fire disturbance and climate change on boreal forest productivity and evapotranspiration. Science of the Total Environment, 362, 85-102.

Kasischke ES, Turetsky MR (2006) Recent changes in the fire regime across the North American boreal region - spatial and temporal patterns of burning across Canada and Alaska. Geophysical Research Letters, 33, L09703, doi: 10.1029/ 2006GL025677.

Kelliher FM, Lloyd J, Arneth A et al. (1997) Evaporation from a central Siberian pine forest. Journal of Hydrology, 205, 279-296.

Kimball JS, Thornton PE, White MA, Running SW (1997a) Simulating forest productivity and surface-atmosphere carbon exchange in the BOREAS study region. Tree Physiology, 17, 589-599.

Kimball JS, White MA, Running SW (1997b) BIOME-BGC simulations of stand hydrological processes for BOREAS. Journal of Geophysical Research - Atmospheres, 102, 29043-29051.

Krishnan P, Black TA, Grant NJ, Barr AG, Hogg EH, Jassal RS, Morgenstern K (2006) Impact of changing soil moisture distribution on net ecosystem productivity of a boreal aspen forest during and following drought. Agricultural and Forest Meteorology, 139, 208-223.

Kurz WA, Apps MJ (1999) A 70-year retrospective analysis of carbon fluxes in the Canadian forest sector. Ecological Applications, 9, 526-547.

Kurz WA, Dymond CC, Stinson G et al. (2008) Mountain pine beetle and forest carbon feedback to climate change. Nature, 452, 987-990.

Lafleur PM (1992) Energy balance and evapotranspiration from a sub-arctic forest. Agricultural and Forest Meteorology, 58, 163 175.
Lafleur PM, McCaughey JH, Joiner DW, Bartlett PA, Jelinski DE (1997) Seasonal trends in energy, water, and carbon dioxide fluxes at a northern boreal wetland. Journal of Geophysical Research - Atmospheres, 102, 29009-29020.

Linder S, Troeng E (1980) Photosynthesis and transpiration of a 20-year-old Scots pine. In: Structure and Function of Northern Coniferous Forests - An Ecosystem Study, Vol. 32 (ed. Persson T), pp. 165-181. Ecological Bulletin 32, Stockholm.

Longton RE (1992) The role of bryophytes and lichens in terrestrial ecosystems. In: Bryophytes and Lichens in a Changing Environment (eds Bates JW, Farmer AW), pp. 32-76. Clarendon Press, Oxford.

Mackay DS, Ewers BE, Cook BD, Davis KJ (2007) Environmental drivers of evapotranspiration in a shrub wetland and an upland forest in northern Wisconsin. Water Resources Research, 43, W03442, doi: 10.1029/2006WR005149.

Malmström CM, Raffa KF (2000) Biotic disturbance agents in the boreal forest: considerations for vegetation change models. Global Change Biology, 6, 35-48.

Monteith JL (1965) In: Symposia of the Society for Experimental Botany, Vol. 19, pp. 205-224.

National Wetlands Working Group (1988) Wetlands of Canada. Ecological Land Classification Series, No. 24. Sustainable Development Branch, Environment Canada, Ottawa, Ontario, 452 pp.

Neff JC, Harden JW, Gleixner G (2005) Fire effects on soil organic matter content, composition, and nutrients in boreal interior Alaska. Canadian Journal of Forest Research, 35, 2178-2187.

Pejam MR, Arain MA, McCaughey JH (2006) Energy and water vapour exchanges over a mixedwood boreal forest in Ontario, Canada. Hydrological Processes, 20, 3709-3724.

Pietsch SA, Hasenauer H (2006) Evaluating the self-initialization procedure for large-scale ecosystem models. Global Change Biology, 12, 1-12.

Pietsch SA, Hasenauer H, Kucera J, Cermák J (2003) Modeling effects of hydrological changes on the carbon and nitrogen balance of oaks in floodplains. Tree Physiology, 23, 735-746.

Price AG, Dunham K, Carleton TJ, Band LE (1997) Variability of water fluxes through the black spruce (Picea mariana) canopy and feather moss (Pleurozium schreberi) carpet in the boreal forest of Northern Manitoba. Journal of Hydrology, 196, 310-323.

Proctor MCF (2000) Mosses and alternative adaptation to life on land. New Phytologist, 148, 1-6.

R Development Core Team (2007) R: a language and environment for statistical computing. R Foundation for Statistical Computing, Vienna, Austria. ISBN 3-900051-07-0, http://www. R-project.org.

Roberts J (1983) Forest transpiration: a conservative hydrological process. Journal of Hydrology, 66, 133-141.

Running SW, Coughlan JC (1988) A general model of forest ecosystem processes for regional applications. I. Hydrological balance, canopy gas exchange and primary production processes. Ecological Modelling, 42, 125-154.

Running SW, Gower ST (1991) FOREST-BGC, a general model of forest ecosystem processes for regional applications. II. Dynamic carbon allocation and nitrogen budgets. Tree Physiology, 9, 147-160. 
Running SW, Hunt RE (1993) Generalization of a forest ecosystem process model for other biomes, BIOME-BGC, and an application for global-scale models. In: Scaling Physiologic Processes: Leaf to Globe (eds Ehleringer JR, Field CB), pp. 141158. Academic Press, San Diego, CA.

Sass AP (2007) Energy, water, and carbon budgets of young post-fire boreal forests in central Saskatchewan. MS thesis, University of Manitoba, Winnipeg, MB.

Sellers PJ, Bouana L, Collatz GJ et al. (1996) Comparison of radiative and physiological effects of doubled atmospheric $\mathrm{CO}_{2}$ on climate. Science, 271, 1402-1406.

Sellers PJ, Hall FG, Margolis HA et al. (1995) The boreal ecosystem-atmosphere study (BOREAS): an overview and early results from the 1994 field year. Bulletin of the American Meteorological Society, 76, 1549-1577.

Skre O, Oechel WC (1981) Moss functioning in different taiga ecosystems in interior Alaska. Oecologia, 48, 50-59.

Sonnentag O, Chen J, Roulet NT, Ju W, Govind A (2008) Spatially explicit simulation of peatland hydrology and carbon dioxide exchange: influence of mesoscale topography. Journal of Geophysical Research - Biogeosciences, 113, G02005, doi: 10.1029/ $2007 J G 000605$.

Stocks BJ (1991) The extent and impact of forest fires in northern circumpolar countries. In: Global Biomass Burning (ed. Levine JS), pp. 197-202. MIT Press, Cambridge, MA.

Stocks BJ, Mason JA, Todd JB et al. (2003) Large forest fires in Canada, 1959-1997. Journal of Geophysical Research - Atmospheres, 108, 8149, doi: 10.1029/2001JD000484.

Suzuki K, Kubota J, Yabuki H, Ohata T, Vuglinsky V (2007) Moss beneath a leafless larch canopy: influence on water and energy balances in the southern mountainous taiga of eastern Siberia. Hydrological Processes, 21, 1982-1991.

Tang J, Bolstad PV, Ewers BE, Desai AR, Davis KJ, Carey EV (2006) Sap flux - upscaled canopy transpiration, stomatal conductance, and water use efficiency in an old growth forest in the Great Lakes region of the United States. Journal of Geophysical Research - Biogeosciences, 111, G02009, doi: 10.1029/2005JG000083.

Thornton PE (1998) Regional ecosystem simulation: combining surface- and satellite-based observations to study linkages between terrestrial energy and mass budgets. PhD thesis, University of Montana, Missoula, MT, 280 pp.

Thornton PE, Law BE, Gholz HL et al. (2002) Modeling and measuring the effects of disturbance history and climate on carbon and water budgets in evergreen needleleaf forests. Agricultural and Forest Meteorology, 113, 185-222.

Valeo C, Beaty K, Hesslein R (2003) Influence of forest fires on climate change studies in the central boreal forest of Canada. Journal of Hydrology, 280, 91-104.

Viereck LA (1983) The effects of fire in black spruce ecosystems of Alaska and northern Canada. In: The Role of Fire in Northern Circumpolar Ecosystems (eds Wein RW, MacLean DA), pp. 201220. John Wiley \& Sons, New York.

White MA, Thornton PE, Running SW, Nemani RR (2000) Parameterization and sensitivity analysis of the BIOME-BGC terrestrial ecosystem model: net primary production controls. Earth Interactions, 4, 1-85.

Zhang Y, Li C, Trettin CC, Li H, Sun G (2002) An integrated model of soil, hydrology, and vegetation for carbon dynamics in wetland ecosystems. Global Biogeochemical Cycles, 16, 1061, doi: 10.1029/2001GB001838. 